\title{
Sciendo
}

DOI: $10.2478 /$ lpts-2018-0017

\section{SOFTWARE ALGORITHM SYNTHESIS FOR DIESEL ELECTRONIC CONTROL UNIT}

\author{
A.Prohorenko ${ }^{1}$, P. Dumenko ${ }^{2}$ \\ ${ }^{1}$ National Technical University "Kharkiv Polytechnic Institute" \\ 2 Kyrpychova Str., Kharkiv, 61002, UKRAINE \\ ${ }^{2}$ DiGas Ltd. \\ 31 Talsu soseja, K-17-34, Jurmala, LV-2016, LATVIA \\ e-mail: p.dumenko@digasgroup.lv
}

\begin{abstract}
Nowadays global engine construction gets significant progress at a technological level, but specified manufacturers do not release any information about the composition, the structure of the algorithms and the software used by their equipment. It is possible to obtain information only fragmentary and, for example, the description of the electronic control unit algorithm is completely missing. This is a barrier for small companies to improve and adjust existing engines for specific purposes. The present paper describes and develops algorithm synthesis for an electronic diesel engine regulator. Mathematical modelling of the automatic control system has been carried out within the framework of the research. The results of the research have demonstrated the efficiency and sustainability of automatic electronic control system using the proposed algorithm.
\end{abstract}

Keywords: diesel, electronic regulator, mathematical modelling, revolutions, transitional process

\section{INTRODUCTION}

As it is known, diesel engine power management is based on forced change in quality of the mixture supplied to a cylinder (the so-called "quality power management") [1]. In practice, the implementation of internal mixture formation leads to the need to control the amount of fuel injected into the cylinder, which is called cyclic injection. The dosing of this cycle feed is provided by high pressure fuel equipment (FE), which is an essential part of any diesel engine. Thus, the task of managing a diesel engine is basically up to its fuel equipment management.

Conventional mechanical management system of crankshaft speed with a variety of devices ensures a sufficiently high precision cycling dosage of fuel supply at different diesel engine speeds. However, it has limited features and ignores many external factors that affect its functioning. In addition, the minimum response time of mechanical system is limited to its design [2], [3]. 
Significant progress in global engine building was achieved through the use of electronic components to manage the components and systems in modern engine designs. Electronic control of diesel engine fuel supply allows the injection process parameters to be controlled accurately and differentially. This is the only way to comply with numerous requirements that are put before modern diesel engines [4].

However, mass production and equipment of diesel engines with electronically controlled fuel equipment is the prerogative of several leading world manufacturers, primarily Bosch, Heinzmann (Germany), Delphi (USA), Motorpal (Czech Republic) and several others. Monopoly ownership of these technologies allows these manufacturers to make super-profits, overstating reasonable costs of such systems as well as the works on their adaptation to the management object. Therefore, it is natural that the specified manufacturers do not release any information about the composition, the structure of the algorithms and the software used by their equipment. The same approach to business is kept by small private companies engaged in fitting electronic management to conventional fuel equipment.

Available open sources and publications only disclose that electronic diesel engine management system includes a set of sensors in a particular configuration. Usually these are the following: engine speed sensor, position sensor (both are obligatory), sensor of the position of high pressure fuel pump rail; temperature fuel, boost pressure, boost temperature, exhaust gases and coolant temperature sensors; executive mechanism in the form of an electromagnet, linear piezoactuator or step motor; electronic control unit (ECU) that connects sensors and executive components by means of its algorithm [4]. However, the description of the ECU algorithm is completely missing. Fragmentary it is known that it processes signals from the sensors and based on the interpolation of the tables in its memory sends control signals to the actuators [4]. Typically, the sets of tables, their purpose and method of forming control signals are not disclosed as commercial secrets (know-how) of the manufacturers.

Therefore, it is relevant to solve scientific and technological problems to create an open source algorithm for a diesel engine power management system for fuel supply, which is the goal of the present article.

\section{THE AREA AND METHOD OF RESEARCH}

Modern diesel engine fuel systems are divided into two types: fuel equipment with mechanic slide dosage valve drive (cutoff edge on plunger) and FE with solenoid-valve, independent of the plunger movement dosage values of cycle fuel supply. It is clear that the first type can be controlled both mechanically and electronically, while the second one can only be electronic [5]. Advantages and disadvantages of the first and second types of FE are well described in the literature (e.g. [4]), and, therefore, there is no point to focus on it thoroughly in the present paper.

It should be kept in mind that in order to create an electronic system to manage an internal combustion engine, it is necessary to solve tasks from different fields of knowledge. First of all, the system creation requires knowledge of electronics and mechatronics for the development and production of principal and assem- 
bly schemes, component selection, as well as selection of the set of sensors and actuators. In addition, the algorithm synthesis and programming code of the ECU processor require the knowledge of the theory of internal combustion engines, the theory of automatic control and low-level programming. Thus, it is possible to admit that the task of development of electronic diesel engine management system is only possible using a synergistic approach in the first place.

\section{SETTING UP RESEARCH PROBLEMS}

Description of theoretical foundations of electronic diesel engine management and the need for individual sensors are considered in the studies [7], [8]. At first glance, it seems that based on the theory of ICE and the theory of automatic control it does not take a lot of effort to synthesise the necessary algorithm. However, real-life implementation encounters necessary unambiguous matters. For example, the implementation of the proportional integral-differential (PID) regulation (and the theory of automatic control tells us that the majority of electronic controls are based on such an algorithm [6]), is based on the known residual value, i.e., the deviation of the current controlled variable value from the required or desired one. In the case of a diesel regulator, this is the deviation of the current speed of the crankshaft from the desired one. But in order to define the "desired" speed of the engine, working by speed or regulatory (static) characteristics it is necessary to know or determine the current value of load resistance loaders, which is not only difficult to be measured, but also depends on the regulated parameter value (generally it is considered that the moment of load resistance is proportional to the square of the engine speed [1]). Thus, the problem becomes algorithmically insoluble.

\section{MANAGEMENT ALGORITHM GROUNDED ON BASE TABLES AND PID CONTROLLER}

A rather simple and obvious solution to the problem mentioned above is the use of the calculation of the load resistance moment with the help of the dynamic mathematical model of the engine to be controlled. This model can be introduced into the ECU algorithm and based on the equations of the object movement and statistical table data for its work parameters. Then, the result of the calculation of this mathematical model as the current value of the load resistance moment $\left(M_{c}\right)$ is transmitted into a tabular interpolation algorithm to determine the engine speed $n_{p}$, which corresponds exactly to the stable operational mode for the obtained value $M_{c}$. This value $n_{p}$ will be necessary (specified), i.e., "desired" for the engine. Next, comparing the obtained value $n_{p}$ to the readings of the current engine speed sensor $n_{i}$, the residual value is received for the PID controller algorithm, which calculates the signal to the fuel supply actuator.

Accordingly, an appropriate algorithm of the ECU should be based on a set of base tables and special formulas, including PID controller formula and the internal mathematical model predictive equation:

- $\quad V_{c}=f\left(H p, n_{i}\right)$ - basic fuel supply table, dependence of volumetric cyclic 
fuel supply by HPFP $\left(V_{c}\right)$ on rail position ( $\left.H p\right)$ and engine speed;

- $\quad B_{c}=f\left(V_{c}, T_{T o n}\right)$ - table (formula) of fuel density, dependence of mass cyclic fuel supply by HPFP $\left(B_{c}\right)$ on volumetric cyclic feed and its temperature $\left(T_{\text {Fuel }}\right)$;

- $\quad M=f\left(n_{i}, B_{c}\right)$ - basic engine torque table, the dependence of engine torque $(M)$ on engine speed and mass cyclic fuel supply;

- $M_{c}=f\left(M, n_{i}, n_{i-1}\right)$ - the equation of internal mathematical model, which connects the current engine torque $(M)$ and the change of crankshaft speed $\left(n_{i}, n_{i-1}\right)$ the moment of load resistance $\left(M_{c}\right)\left(n_{i-1}-\right.$ previous (at the previous calculation cycle) value of the crankshaft speed sensor);

- $n_{p}=f\left(X, M_{c}\right)-$ table of equilibrium rotational frequencies;

- $H p_{i}=H p_{i-1}-K p\left(n_{i}-n_{p}\right)-K d\left(n_{i}-n_{i-1}\right)-K i \sum_{k=1}^{N i}\left(n_{i}-n_{p}\right)_{k}-$ current relative position of the HPFP rail by PID control ( $\mathrm{Kp}, \mathrm{Kd}, \mathrm{Ki}, \mathrm{Ni}$ - specified values of PID-controller).

Then the table interpolations and calculations in the ECU algorithm are to be carried out cyclically in such a sequence.

The beginning of the cycle. According to the values of the engine speed sensor and HPFP rail position (parameters that uniquely determine the mode of engine operation) from the table $V_{c}=f\left(H p, n_{i}\right)$ using two-dimensional linear interpolation the volumetric cyclic fuel supply required for this mode is calculated. This table can be experimentally obtained from the hydraulic characteristics of high pressure fuel system [7]. An example of such a table can be found in Fig. 1.

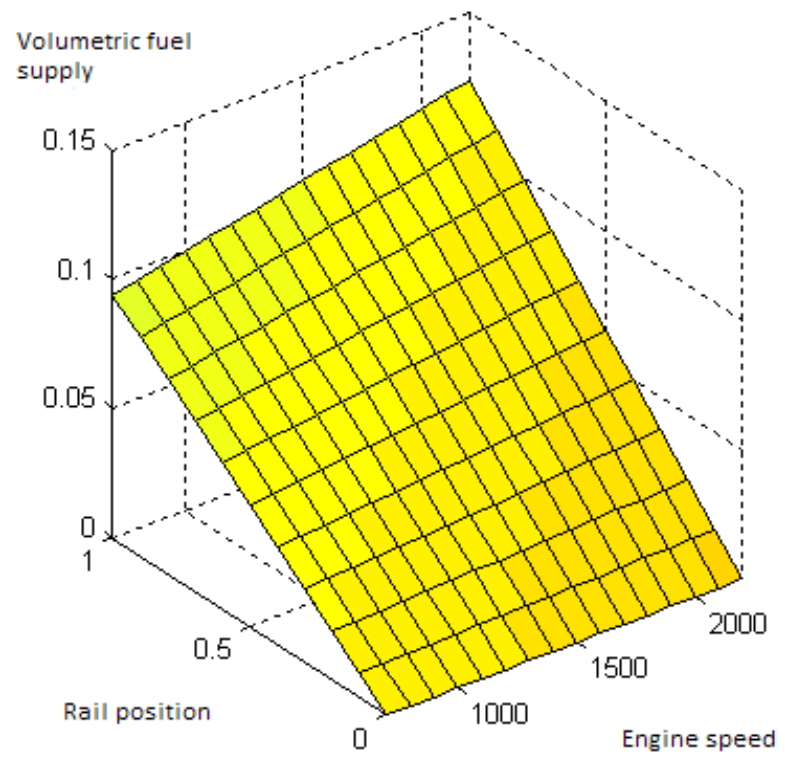

Fig. 1. An example of a basic fuel supply table. 
By the found value of the volumetric cyclic fuel supply $\left(V_{c}\right)$ and the data of the fuel temperature sensor $\left(T_{\text {Fuel }}\right)$ from the table $B_{c}=f\left(V_{c}, T_{\text {Fuel }}\right)$ corresponding mass cyclic fuel supply is determined. An example of such a table is shown in Fig. 2. In fact, this table is a fuel density table and can be replaced with the formula that relates the fuel density to its temperature, for example, $B_{c}=V_{c}\left(\rho_{20}-0,000725 \cdot\left(T_{\text {Fuel }}-20^{\circ}\right)\right)$, where $\rho_{20}$ - the fuel density under normal conditions.

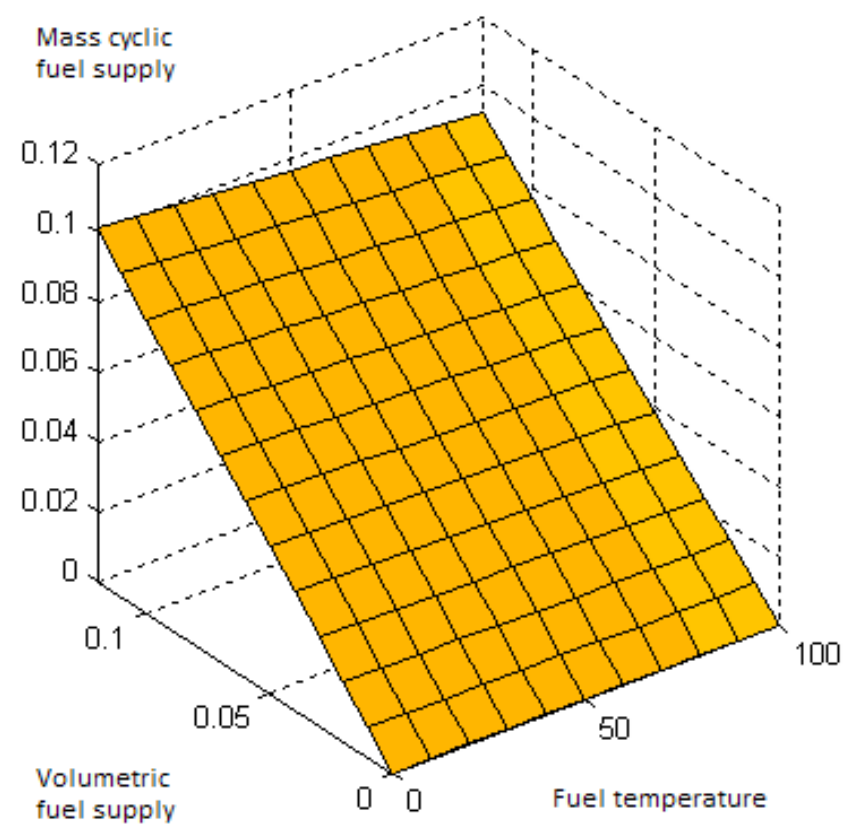

Fig. 2. Correction table by fuel temperature.

By the found value of the mass cyclic fuel supply $\left(B_{c}\right)$ and the current data from the engine speed sensor $(n)$ from the table $M=f\left(n_{i}, B_{c}\right)$ current efficient engine torque is determined. Basic engine table $M=f\left(n_{i}, B_{c}\right)$ is determined experimentally, for example, according to the measured load characteristics [7]. Such a table is possible to see in Fig. 3. Table contains static engine characteristics.

Basic equation of internal predictive mathematical engine model enables us to determine the current value of loading resistance moment by the relation $M_{c}=f\left(M, n_{i}, n_{i-1}\right)$. It is shown below how to derive this relation, hereon the basic equation of internal predictive mathematical model.

Using the data from the control sensor (pedal or lever) $(X)$ and the calculated value of the current loading resistance moment $\left(M_{c}\right)$ by the table $n_{p}=f\left(X, M_{c}\right)$ balanced engine speed is determined as the desired parameter. An example of such a table is shown in Fig. 4. It should be noted that the creation of this table is very difficult. It can be obtained having re-orientated the table of balanced engine modes $M=f(X, n)$ that in its turn is to be determined experimentally.

PID-controller algorithm calculates the necessary position of the HPFP rail $\mathrm{Hp}$ and then the ECU sends a proportional control signal to the rail actuator mechanism. 


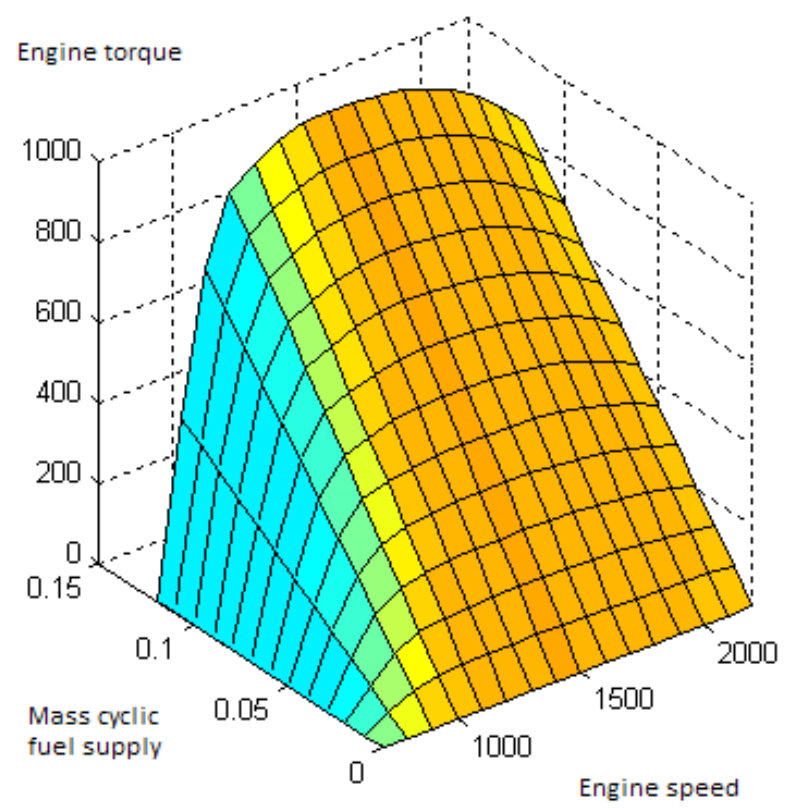

Fig. 3. An example of a basic engine table.

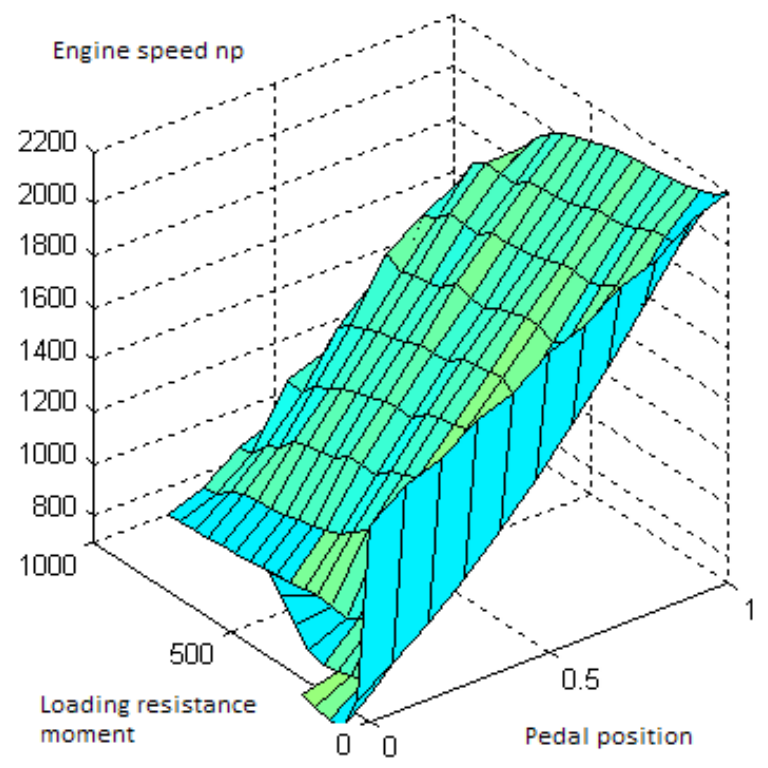

Fig. 4. An example of a balanced engine speed table.

End of cycle. The algorithm described above has a significant advantage, which is a possibility to use PID control in order to achieve necessary quality of transitional processes depending on engine purpose, mode of operation, technical condition and environmental conditions. Thus, it will allow such a management system to be created, which is close to adaptive.

However, this algorithm has also drawbacks. Among them there is a necessity of massive experimental research for filling in basic tables, as well as identifica- 
tion of internal mathematical model and PID controller adjustments. Moreover, in practice, there will be deviations of an individual engine options from others, which requires experimental modifications of base tables to fit a particular design. It should also be kept in mind that the parameters of the engine in the table (in particular the effective engine torque) depend on the thermal state of the engine, environmental conditions, fuel quality, technical condition of the components, etc. For consideration of these conditions the algorithm may require the introduction of additional tables, adjusting coefficients etc. that will inevitably lead to its complication.

\section{BASIC EQUATION OF THE INTERNAL MATHEMATICAL MODEL}

The equation to predict the engine loading resistance moment value can be deduced in the following way.

The known equation of engine dynamics, which in fact is the second Newton's law for rotational movement, taking into account D'Alamber's principle [3]:

$$
J \frac{d \omega}{d t}=M-M_{c}
$$

where $J$ - the inertia mass moment of the rotating engine parts, $\omega$ - the current angle crankshaft speed, $M$ - the engine torque, $M_{c}$ - the loading resistance moment.

It is obvious that $\omega=d \varphi / d t$, where $\varphi$ - the current angle of the crankshaft turn. Then the equation (1) can be put down in the following manner:

$$
J \omega \frac{d \omega}{d \varphi}=M-M_{c} .
$$

Getting from minor to final increments of variables, it is possible to indicate $\omega \approx \omega_{c p}=\left(\omega_{i}+\omega_{i-1}\right) / 2$, which is the average angular velocity for two previous measurements $\omega_{i}$ and $\omega_{i-1}$. Taking into account that the increase of the angular velocity for two previous measurements is $\Delta \omega=\omega_{i}-\omega_{i-1}$ and inserting everything into expression (2):

$$
J \frac{\omega_{i}+\omega_{i-1}}{2} \cdot \frac{\omega_{i}-\omega_{i-1}}{\Delta \varphi}=M-M_{c} .
$$

It is possible to see that the numerator on the left is the difference of squares:

$$
J \frac{\omega_{i}^{2}-\omega_{i-1}^{2}}{2 \cdot \Delta \varphi}=M-M_{c} .
$$

The known correlation of the angular velocity to the engine speed is $\omega=\frac{\pi}{30} n$. Using it in equation (4) it is possible to obtain:

$$
\frac{J}{2 \cdot \Delta \varphi}\left(\frac{\pi}{30}\right)^{2}\left(n^{2}-n_{0}^{2}\right)=M-M_{c} .
$$


Getting to the degree of the crankshaft turn increment $\Delta \varphi=\Delta \varphi^{\circ} \cdot \frac{\pi}{180}$, and inserting it into (5):

$$
\frac{\pi^{2} J\left(n^{2}-n_{0}^{2}\right)}{1800 \cdot \Delta \varphi^{\circ} \cdot \frac{\pi}{180}}=M-M_{c} .
$$

After shortenings it is possible to obtain the following expression:

$$
\frac{\pi J}{10 \cdot \Delta \varphi^{\circ}}\left(n^{2}-n_{0}^{2}\right)=M-M_{c} .
$$

Thus, it is possible to determine the desired value of the loading resistance moment:

$$
M_{c}=M-\frac{0,314 \cdot J}{\Delta \varphi^{\circ}}\left(n^{2}-n_{0}^{2}\right) .
$$

And this is the expression to be used for calculations in engine management algorithm, where $\Delta \varphi^{\circ}$ is constant, which can be equal to $\Delta \varphi^{\circ}=360^{\circ}$ or $720^{\circ}$.

\section{SIMULATION RESULTS OF TRANSITIONAL PROCESSES}

For preliminary confirmation of the accuracy of the suggestions mentioned above, the authors of the present paper carried out calculation studies of diesel engine transitional processes provided by the proposed electronic regulator algorithm. The calculations were carried out according to the mathematical model of diesel engine management system described in the paper [5]. A virtual diesel engine was selected as an example for calculation purposes. It was accepted that the initial balanced operation mode had the following parameters: control position $X_{0}=0.7$, engine speed $n_{0}=1640 \mathrm{rpm}$. The authors also studied the reaction of the engine management system to external independent controlling and activating influence.

System reaction to controlling influence. At the moment of time $t=1 \mathrm{sec}$, a controlling influence is applied to the system by moving the control by a relative number $\Delta X=0.2$. At the same time, a speed transitional process shown in Fig. 5 takes place. It is possible to see the values of the current balanced engine speed (dashed line), which are calculated using the internal mathematical algorithm model. As it can be seen in Fig. 5, as a result of the transitional process in 2 seconds the engine accelerates to $n=1930 \mathrm{rpm}$ and reaches a new balanced mode, which is evidence of correct functioning of the proposed regulator algorithm.

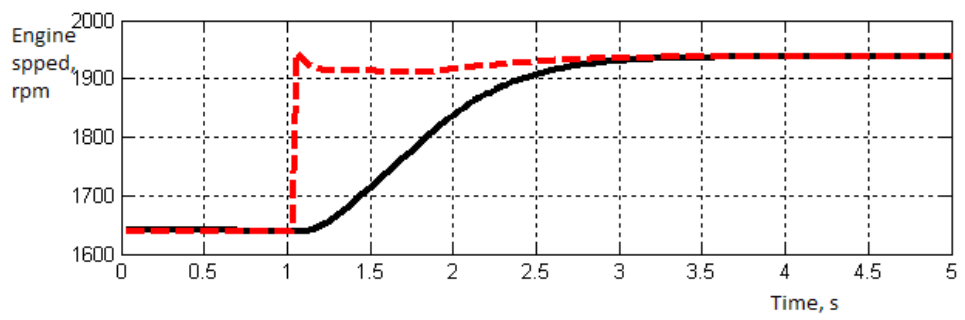

Fig. 5. Speed transitional process under control. 
The movement of the HPFP rail during this transitional process is shown in Fig. 6. As it can be seen, in the transitional process the engine (HPFP rail) does not reach external speed characteristics like it often takes place while working with a mechanical all-mode regulator.

System reaction to activating influence. At the moment of time $t=1 \mathrm{sec}$, an activating influence is applied to the system in the form of loading resistance moment increase by the value $\Delta M_{c}=200 \mathrm{~N} \times \mathrm{m}$. At the same time, a speed transitional process shown in Fig. 7 takes place. It is possible to see the values of the current balanced engine speed (dashed line), which are calculated using the internal mathematical algorithm model. As a result of the transitional process, in 2 seconds the engine reaches a new balanced mode $n=1577 \mathrm{rpm}$, which is evidence of correct functioning of the proposed regulator algorithm.

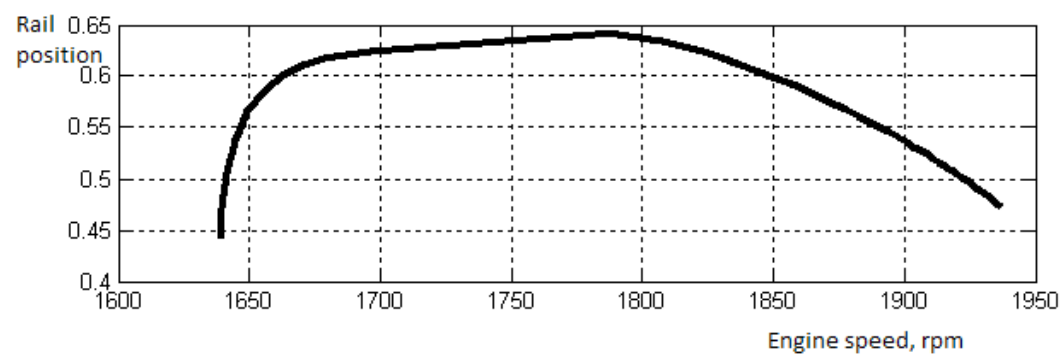

Fig. 6. HPFP rail movement in the transitional process under control influence in the frequency area.

The HPFP rail movement in the transitional process in the frequency area is shown in Fig. 8. The HPFP rail movement in transitional process takes place along certain control characteristics.

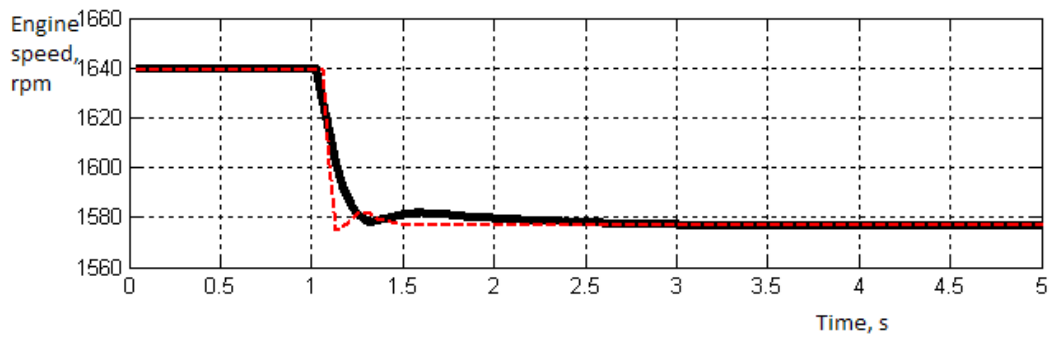

Fig. 7. Speed transitional process under activating influence.

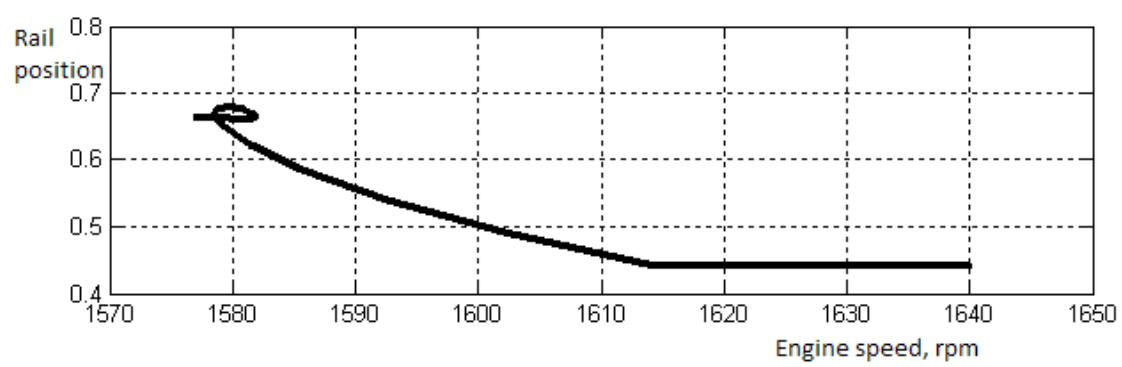

Fig. 8. HPFP rail movement in the transitional process under activating influence in the frequency area. 
The presented algorithm of electronic diesel engine management systems has prospects in the following areas:

- Creation of control algorithms for turbocharged engines. Implementation of the dependence of fuel supply on boost pressure is only a limiting factor aimed at smoke reduction and engine torque reduction during acceleration. In the first approach, this dependence can be described in additional tables of current cyclical supply limitation by airflow such as $B_{c}=f\left(G_{A i r}, n\right)$.

The management of injection advance angle, gas recycling, turbocharger and several other matters can also be successfully solved while developing this algorithm.

- Management algorithm adaptation in diesel engines with electronic valve actuator of the fuel equipment. This algorithm can manage diesel engines with electromagnetic injectors or HPFP and even Common-Rail system. In this case, the signal sent by the controller in form of the position of the fuel rail is substituted by the time signal sent to the corresponding actuator. However, the Common-Rail system requires taking into account the dependence of the cyclic supply amount on the fuel pressure in the accumulator, which can be solved using additional basic tables such as $V_{c}=f\left(\tau_{\text {inj }}, p_{\text {Fuel }}\right)$ and $p_{\text {Ton }}=f(X, n)$.

\section{CONCLUSIONS}

1. The research has developed and described the concept of open algorithm synthesis for electronic diesel engine control based on basic tables and PID-control.

2. The research has deduced the basic equation of internal predictive mathematical model of the algorithm, which connects current engine torque and engine speed change to loading resistance moment.

3. Calculation studies by mathematical model have demonstrated workability and stability of the system engine-load under this algorithm.

\section{ACKNOWLEDGEMENTS}

The research leading to these results has been supported by the European Regional Development Fund project "Development of Competence Centre of Mechanical Engineering”, contract No.1.2.1.1/16/A/003 signed between Competence Centre of Mechanical Engineering and Central Finance and Contracting Agency, Research No. 3.2 "Dual Fuel System Development for a Diesel Engine Locomotive".

\section{REFERENCES}

1. Vyrubov, D. N., Ivashchenko, N. A. \& Ivin, V. I. (1983). Internal combustion engines. Theory of piston and combined engines: Workbook for higher technical educational establishments. M.: Machine-building. 
2. Prokhorenko, A. A. (2014). Automatic management of internal combustion engines (tuition manual). Kharkiv: Pidruchnyk NTU KhPI.

3. Krutov, V.I. (1989) Automatic management and control of internal combustion engines. M.: Machine-building.

4. Diesel engine management systems. (2004). M.: JSC "Magazine "Za rulyom".

5. Prokhorenko, A. A. (2015). Mathematical description of diesel engine AMS with electronic regulator in the environment of conditions. Internal Combustion Engines, 1, 14 20.

6. Besekerskiy, V. A., \& Popov, E. P. (2003). Theory of automatic management systems. Saint-Petersburg: Publishing House "Profession".

7. Prokhorenko, A. O., \& Meshkov, D. V. (2008). Basic fuel management characteristics of Common Rail diesel engines. Internal Combustion Engines, 2, 39-43.

8. Prokhorenko, A. O. (2009). Algorithm of Common Rail diesel engines fuel management. Theoretical elements. Internal Combustion Engines, 2, 69-74.

\title{
DĪZEL̨MOTORA VADĪBAS BLOKA PROGRAMMATŪRAS ALGORITMA SINTĒZE
}

\author{
A. Prohorenko, P. Dumenko
}

Kopsavilkums

Mūsdienās globāla iekšdedzes motoru ražošana saskaras ar nozīmīgu progresu tehnologiiskā līmenī, bet noteikti ražotāji neizplata informāciju par algoritmu struktūru, sastāvu un izmantoto programmatūru. Ir pieejama tikai fragmentāra informācija, un, piemēram, elektroniskā vadības bloka algoritma apraksts pilnībā nav pieejams. Tas traucē mazajām kompānijām veikt esošo motoru uzlabošanu un pielāgošanu konkrētiem mērksiem.

Raksta autori raksturo dīzeļmotora elektroniskā regulatora algoritma sintēzi. Pētîjuma laikā ir veikta automātiskās kontroles sistēmas modelēšana. Iegūtie rezultāti parāda automātiskās elektroniskās kontroles sistēmas efektivitāti un ilgtspējību, ieviešot konkrēto algoritmu.

25.03.2018. 